Article

\title{
Corporate Social Responsibility Disclosure and Stock Price Crash Risk: Evidence from China
}

\author{
Jingwen Dai, Chao Lu * and Jipeng Qi *
}

School of Economics and Management, Beijing Jiaotong University, Beijing 100044, China; 17120491@bjtu.edu.cn

* Correspondence: chaolu@bjtu.edu.cn (C.L.); qijp@bjtu.edu.cn (J.Q.)

Received: 22 November 2018; Accepted: 9 January 2019; Published: 16 January 2019

check for updates

\begin{abstract}
We take Chinese A-share listed companies in years 2010-2015 as a sample to examine the relationship between Corporate Social Responsibility (CSR) information disclosure and stock price crash risk using the fixed effect model. The results show that: (1) There is an inverted U-shaped nonlinear relationship between CSR information disclosure and stock price crash risk. That is, as the CSR information disclosure level increases, the CSR information disclosure first aggravates and then reduces the stock price crash risk; (2) under different disclosure motives, there is a significant difference in the impact of CSR information disclosure on stock price crash risk. There is still an inverted U-shaped relationship between mandatory CSR information disclosure and stock price crash risk, but not for the semi-mandatory and voluntary disclosure; (3) the academic independent director has a positive adjustment effect on the relationship between CSR information disclosure and stock price crash risk, while the institutional investor has a negative adjustment effect on the relationship between CSR information disclosure and stock price crash risk. The research is of great significance for promoting the fulfillment of CSR, improving corporate governance and stabilizing the capital market.
\end{abstract}

Keywords: Corporate Social Responsibility (CSR); stock price crash risk; academic independent director; institutional investor

\section{Introduction}

Stock price crash risk measures the possibility of a stock price collapse of a listed company, which can be attributed to principal-agent problems and information asymmetry [1,2]. There is a principal-agent relationship between the shareholders and the management of listed companies, so the management may act to harm the interests of the external investors in the specific business management process for personal gain. It is generally believed that management has the motive to conceal negative news within the company for self-interest purposes, such as rights, remuneration and reputation, which makes the stock price deviates from the intrinsic value of the company. As negative information accumulates and erupts, investors begin to sell the stocks, making the stock price of the company more likely to collapse. As a result, the stock price crash risk arises [3]. In addition to impacting the capital market, the stock price crash risk may also lead to misallocation of resources and negative effects on the real economy [4]. In recent years, the skyrocketing and tumbling phenomenon of Chinese capital market has been ranked among the world's top [5]. Especially since 2015, the sharp rise and fall of Chinese stock market has caused a huge impact on financial market stability and investor wealth, and the extreme tail event risk, such as stock price crash risk has attracted more and more attention.

Corporate Social Responsibility (CSR) information disclosure is an important way of non-financial information disclosure. Theoretically, it is an important factor affecting the quality of corporate information disclosure and the stock price crash risk. CSR refers to the pursuit of social welfare 
maximization and sustainability through effective management to assume corporate responsibility for all stakeholders [6,7]. With the increasing importance of sustainability, that enterprises should increase CSR information disclosure has been widely recognized by various countries [8,9]. According to statistics from Rankings CSR Ratings (RKS), the number of Chinese A-share listed companies that issued social responsibility reports increased from 471 in 2010 to 701 in 2015. Some listed companies of Shanghai Stock Exchange and Shenzhen Stock Exchange were required to issue CSR reports by the China Securities Regulatory Commission (CSRC) in December 2008, while other listed companies can choose to voluntarily disclose. It symbolizes the coexistence of mandatory and voluntary disclosure in China's CSR reports, which is also the main classification of existing research. Besides, the status of central enterprises affiliated with the State-owned Assets Supervision and Administration Commission of the State Council (SASAC) is relatively special. In addition to economic responsibilities, the central enterprises also bear more political and social responsibilities. In January 2008, the SASAC issued the document about The Guidance for the Central Enterprises to Disclose Their Social Responsibilities Information, clearly encouraging the central enterprises to issue CSR reports. According to statistics, under the call of the SASAC, central enterprises will actively publish CSR reports for their special state-owned status. In 2014 and 2015, about 75.89\% and 57.55\% of central enterprises chose to issue CSR reports respectively [10]. Since the disclosure motivation of central enterprises lies between compulsory and voluntary disclosure, we divide the CSR reports issued by the central enterprises into semi-compulsory disclosure [11]. By examining the different effects of compulsory, semi-compulsory and voluntary disclosure of CSR information on the stock price crash risk, the paper will make up for existing research vacancies [12,13].

Essentially, the stock price crash risk reflects the risk caused by the insufficient disclosure of negative information. However, the existing research on the relationship between CSR information disclosure and stock price crash risk is still inconclusive. Also, there is a lack of detailed research from the perspectives of internal and external corporate governance mechanisms. Theoretically, enterprises that actively participate in social welfare and environmental protection activities tend to disclose sufficient and objective CSR information to maintain relationships with employees, consumers and shareholders. Moreover, due to social responsibility awareness and sustainable development considerations, the management will also actively disclose negative news inside the company to investors, so that the stock price can more accurately reflect its intrinsic value and reduce the stock price crash risk [13]. But if the management uses the CSR report as a self-interest tool to convey to investors a good image of CSR through whitewashed and vague description [14], CSR information disclosure may increase the stock price crash risk. Therefore, whether CSR information disclosure plays the role of "market stabilizer" or "market destroyer" remains to be further explored.

The paper takes 1478 Shanghai and Shenzhen A-share listed companies in 2010-2015 years as samples to explore the impact of CSR disclosure under different motives on the stock price crash risk, and further examine the regulating effect of internal and external corporate governance factors. The innovation and contribution of this paper are mainly reflected in: (1) We innovatively put forward the differentiation of semi-mandatory disclosure of CSR reports, which is more in line with the reality in China and more precise. The research based on different motivations of CSR information provide an empirical reference for the supervision of non-financial information disclosure behavior of listed companies; (2) the paper finds the nonlinear relationship between CSR information disclosure and stock price crash risk, which will broaden the theoretical research on the economic consequences of CSR, provide reference for improving the quality of corporate governance, protecting the interests of investors and stabilizing the capital market from a new perspective. Also, the results provide a decision-making reference for policymakers and regulators in the normative of CSR information.

The rest of this paper is organized as follows: The second part is the literature review and research hypothesis. We put forward research hypotheses based on the literature at home and abroad. The third part is the empirical study, mainly including explanations of the sample, variables and 
models. The fourth part is the analysis of empirical results for each research hypotheses. The empirical results are summarized and the contribution in theory and practice is explained in the last part.

\section{Literature Review and Research Hypothesis}

As the sustainability of society drawn more and more attention, the research on CSR has been increasing. But there is no consensus on whether CSR has safeguarded the interests of shareholders or has become a self-interest tool for management. In the early days, research on CSR mainly focused on its definition and meaning. Some scholars believe that CSR mainly covers five aspects: Economy, society, environment, stakeholders, and voluntary behavior [15]. Afterwards, scholars paid more attention to the economic consequences of CSR, mainly involving the impact of CSR on stock price [16], corporate performance and value [17-20], and earnings management, etc. In addition, a few studies have examined the impact of CSR on analysts' earnings forecasts [12], stock price synchronicity and stock price crash risk $[13,21,22]$. Although various aspects of research are involved, there is a lack of in-depth exploration on CSR.

As the information source of listed companies, the CSR information directly affects the negative information content inside the company obtained by investors and is reflected in the stock price crash risk. Chen et al. first proposed the measure of stock price crash risk, which was widely recognized and applied in subsequent research [23]. According to the existing research, the corporate governance factors influencing the stock price crash risk mainly include internal factors and external factors. Among them, internal governance factors involve senior management [24], the board of directors [25], major shareholders and institutional investors [26], and internal control information disclosure [13,27], etc., external factors-including securities analysts [28], media [29], religion [30] and institutional environment [31], etc.

The two major causes of the stock price crash risk are the principal-agent problem and information asymmetry, while CSR information disclosure is an important factor that directly affects the above two major causes. However, the existing literature has not yet reached a consensus on the quality and the effectiveness of CSR information disclosure. Also, less attention is paid to the influence of internal independent directors and other governance factors on the effectiveness of CSR information disclosure. Therefore, whether CSR information disclosure can alleviate information asymmetry and control the stock price crash risk has become the focus of this study.

\subsection{CSR and Stock Price Crash Risk}

As an important behavior of listed companies, theoretically, CSR information disclosure can alleviate information asymmetry between company management and external investors. Enterprises with a strong sense of social responsibility are more inclined to actively improve the quality of information disclosure, thereby reducing the degree of stock price deviation from the company's intrinsic value and reducing the stock price crash risk. But in reality, the effect of CSR information disclosure is controversial. Even listed companies that publish CSR reports may use CSR reports to cover up bad news inside the company and divert shareholders' attention for personal gain, which will exacerbate the principal-agent conflict between management and shareholders and increase the stock price crash risk.

The different level of CSR information disclosure is likely to reflect the different motives of enterprises to issue CSR reports, and thus the impact on the stock price crash risk is different. Enterprises with low CSR information disclosure level are more likely to publish general, formal CSR reports to meet the expectations of the government, investors and the public, and the content of CSR reports is likely to be similar in different years. Especially for those companies with poor performance or earnings management [32,33] and corruption [34], charitable, public welfare, environmental protection and other social responsibility activities are more likely to be carried out to avoid being punished. Also, those companies are more inclined to show their good image to external stakeholders through standardized and vague positive descriptions in the CSR reports [35]. To avoid reputation 
loss, managers are likely to use the CSR report as a self- interest tool for short-term promotion, salary increase and reputation [14], which greatly undermines information transparency. Therefore, when the level of CSR information disclosure is low, the CSR report is more likely to become a self-interest tool for management. The CSR information covers up or delays the disclosure of negative news inside the company, which increases the agency costs and the risks borne by shareholders.

In contrast, the higher CSR information disclosure level is more likely due to the higher ethical standards and codes of conducts of listed companies. Essentially, CSR, as an intangible asset, can enhance the reputation of companies, improve the performance and safeguard the interests of shareholders in the long run. Thereby achieving sustainable development. Under the higher social responsibility standards, internal management will reduce activities, such as insider trading that harm the interests of stakeholders to achieve long-term performance and reputation improvement [36,37]. Also, the tendency to hoard bad news will decrease [21]. Enterprises can strengthen internal and external information communication and reduce information asymmetry by disclosing objective and reliable social responsibility information [38]. At the same time, it mitigates conflicts of interest between stakeholders and management, and helps maintain good relationships with investors and the public $[39,40]$. Therefore, the higher CSR information disclosure level can help improve corporate governance quality, ease proxy conflicts and information asymmetry between shareholders and management, and thus reduce the stock price crash risk [13].

On the whole, we believe that there is a non-linear inverted U-type relationship between the CSR information disclosure level and the stock price crash risk. When the CSR information disclosure level is low, the CSR report is more used as a self-interest tool for management, which increases the stock price crash risk. As CSR information disclosure level rises to a certain level, CSR can reflect the long-term strategic vision of the company and reduce the stock price crash risk. Therefore, hypothesis 1 is as follows:

Hypothesis 1 (H1). There is a non-linear inverted U-type relationship between the CSR information disclosure level and the stock price crash risk.

\subsection{CSR, Disclosure Motivation, and Stock Price Crash Risk}

Different disclosure motivations directly affect the information content and quality of CSR reports. Generally, the management issues CSR reports actively or passively for the motivation of system rules, social expectations, ethical standards or economic interests [41,42], which will directly affect the speed and extent of negative news inside the company being excavated and transmitted to investors. Investor trading behavior based on information will directly affect the stock price stability, which can in turn affect the stock price crash risk.

We classify CSR disclosure motivations into mandatory, semi-mandatory and voluntary disclosure. Mandatory disclosure is based on the requirements of the legal system. The China Securities Regulatory Commission (CSRC) mandates that certain listed companies of Shanghai Stock Exchange and Shenzhen Stock Exchange must release CSR reports. Mandatory disclosure of CSR information is usually timely, sufficient and standardized, but there are also formalized drawbacks. Due to formal legal constraints and public supervision, management will be more cautious in compulsory disclosure of CSR reports, and directly reflected in the management's motivation to conceal bad news and the quality of information disclosure. Especially in the case of the general lack of CSR awareness, the effect of such legal enforcement is more significant. Even when CSR information disclosure level is low, mandatory disclosure of CSR information may increase the stock price crash risk. However, as CSR information disclosure levels increase to a certain level, mandatory disclosure of CSR information will help to suppress management's bad news hoarding behavior and thus reduce the stock price crash risk.

In addition, some companies will voluntarily publish CSR reports, either because of social expectations or ethical standards, or out of self-interest. By voluntarily disclosing CSR information, 
companies can cover up bad news, such as internal illegal transactions and earnings manipulation, and convey a positive image of good performance and strong sense of social responsibility to investors [43], so as to avoid being punished in the short term and make profits at the same time [44]. In contrast, semi-mandatory disclosure is a choice under the consideration of existing rules, ethical standards and social expectations. The paper divide the CSR reports issued by the central enterprises under The Guidance for the Central Enterprises to Disclose Their Social Responsibilities Information (2008) by the SASAC into semi-compulsory disclosure. Compared with mandatory and voluntary motivations, semi-mandatory disclosure of CSR information has the characteristics of moderate standardization and sufficient information, while may be deficient in timeliness. On the whole, it's difficult to guarantee the sufficiency and authenticity of the content of semi-mandatory and voluntary disclosure of CSR reports. Under the pressure of stakeholder benefits, such as employee benefits, environmental pollution, product quality, semi-mandatory and voluntary disclosure motivations become less pure, and internal management may actively screen and manipulate CSR information to meet the public's expectations. It is expected that the tendency to hoard bad news will not decrease. Therefore, the semi-mandatory and voluntary disclosure of CSR information quality will not be greatly improved, and it is difficult to significantly affect the stock price crash risk.

In short, under different disclosure motives, the factors that management considers when publishing CSR reports are different, which leads to different levels of internal bad news disclosure, and the impact on stock price crash risk is inconsistent. Semi-mandatory and voluntary disclosure of CSR information may not have a significant impact on the stock price crash risk, while there is an inverse U-shaped nonlinear relationship between mandatory disclosure of CSR information level and stock price crash risk. Therefore, the following hypothesis is proposed:

Hypothesis 2 (H2). There is an inverted U-type nonlinear relationship between mandatory disclosure of CSR information and stock price crash risk, while semi-mandatory and voluntary disclosure of CSR information has no significant impact on stock price crash risk.

\subsection{CSR, Academic Independent Director and Stock Price Crash Risk}

The independent director system is an important mechanism in corporate governance to ease the principal-agent conflict between shareholders and management [45], but the existing research is controversial about whether independent directors can maintain full independence and full performance. Considering that the proportion of academic independent directors, such as professors, experts and scholars, is the highest among the listed companies in China (according to the statistics of this paper, the average proportion of academic independent directors in 2010-2015 is 51.3\%). The paper mainly discusses the impact of the academic independent director on the relationship between CSR information disclosure and stock price crash risk.

On the one hand, the independent director system requires independent directors to supervise management objectively and independently [46], and curb their bad news hoarding activities. Generally, the higher the proportion of independent directors, the higher the reputation incentives and the greater the supervisory role [25,47]. Academic independent directors mostly come from universities, scientific research institutions and other units. Under the advantages of professional knowledge, social network and reputational incentives [48], academic independent directors can provide more objective and valuable decision-making opinions and supervise management behavior.

On the other hand, in reality, independent directors who express their opposition are more difficult to re-elect, this mechanism seriously undermines the corporate governance role of independent directors. In order to avoid the job promotion and interests being impeded, independent directors usually rarely expressed public negative opinions, and their performance and power exercise are more euphemistic [49]. Due to the limited time and energy of participating in corporate affairs, lack of commercial practice experience, it is difficult for academic independent directors to fully play their supervisory role [50]. Moreover, in China, where the equity is highly concentrated, the board members 
are mostly appointed by the shareholders, making it possible for independent directors to be controlled by major shareholders and unable to effectively protect the interests of minority shareholders. In many cases, some internal information related to the interests of executives is only controlled by management, which greatly limits the role of independent directors [51].

Therefore, academic independent directors may not be able to fully play their corporate governance role, and cannot effectively supervise and constrain bad news hoarding activities of management. When the level of CSR information disclosure is low, academic independent directors cannot effectively prevent the self-interest behavior of management, and will further increase the positive effect of CSR information disclosure on the stock price crash risk. When the level of CSR information disclosure is high, academic independent directors will weaken the negative effect of CSR information disclosure on the stock price crash risk due to the lack of functions. For the above reason, the paper proposes the hypothesis:

Hypothesis 3 (H3). Academic independent directors will strengthen the positive effect of CSR information disclosure on the stock price crash risk, and weaken the negative correlation between the two.

\subsection{CSR, Institutional Investor and Stock Price Crash Risk}

Institutional investors, as shareholders and external supervisors, can rely on their professional capabilities and financial advantages to supervise corporate information disclosure and other governance links effectively, and play a role in restraining stock price plunging and stabilizing the market. In the Chinese capital market, institutional investors may pay more attention to the sustainable development of listed companies, and will be more conscious and motivated to supervise the bad news hoarding behavior of managers. This enables stock prices to objectively reflect the intrinsic value of listed companies and reduce the stock price crash risk [26].

As a result, when the CSR information disclosure level is low, institutional investors will stop bad activities inside the company when they first discover, or they may realize supervision function by selling stocks. This mechanism will reduce the self-interest tendency and bad news hoarding behavior of the management, enable managers to disclose CSR information more objectively and truthfully, and weaken the positive correlation between the CSR information disclosure and the stock price crash risk. When the CSR information disclosure level is high, institutional investors can help to constrain managers' behavior, urge managers to actively fulfill their responsibilities in social welfare, environmental protection, and improve the quality of CSR information disclosure [52]. This further reduces the stock price crash risk, that is, institutional investors can strengthen the negative correlation between CSR information disclosure and stock price crash risk. Based on this, the following hypothesis is put forward:

Hypothesis 4 (H4). Institutional investors will weaken the positive effect of CSR information disclosure on the stock price crash risk, and strengthen the negative correlation between the two.

\section{Empirical Study Design}

\subsection{Sample and Data}

This paper selects all A-shares in 2010-2015 years as the initial sample. Among them, institutional shareholding data are from the Wind database. CSR information disclosure data are from the Rankins CSR Ratings (RKS) database while other data come from the CSMAR database. The industry of listed companies is classified according to the Guidelines for the Classification of Listed Companies issued by CSRC in 2012. To ensure the reliability of the results, the data is processed as follows: (1) Eliminate samples with missing variable data; (2) eliminate ST, *ST companies; (3) in view of the particularity of the financial indicators of financial companies, exclude financial companies; (4) eliminate samples with less than 30 weeks of trading week to ensure the calculation of the stock price crash risk; 
(5) all continuous variables are processed by $1 \%$ up and down Winsorize to eliminate the effects of extreme values. In the end, the paper obtained a total of 6928 sample observations, involving 1478 listed companies.

\subsection{Stock Price Crash Risk Measures}

The dependent variable of this paper is stock price crash risk (CrashRisk). At present, the methods of Chen et al. [23] and Kim et al. [53,54] are widely used to measure the stock price crash risk. First, the model (1) is used for regression to obtain the residual serial $\varepsilon_{i, t}$. The model incorporates the lag and advance terms of the market yield considering the cash dividend reinvestment income:

$$
R i, t=\alpha i+\beta 1 R m, t-2+\beta 2 R m, t-1+\beta 3 R m, t+\beta 4 R m, t+1+\beta 5 R m, t+2+\varepsilon i, t,
$$

where $i$ indicates the $i$-th stock, $t$ indicates the $t$-th trading week, $R_{i, t}$ is individual stock returns considering the cash dividend reinvestment, and $R_{m, t}$ is the average yield weighted by the market capitalization of all Shanghai and Shenzhen A-shares.

After that, the firm-specific yield of stock $i$ in week $t W i, t=\operatorname{Ln}(1+\varepsilon i, t)$ is calculated based on the residual $\varepsilon_{i, t}$. Two indicators are constructed using Equations (2) and (3) to measure the stock price crash risk.

Indicator 1: Negative conditional skewness of returns (NCSKEW)

$$
\text { NCSKEW } i, t=-\left[n(-1)^{\frac{3}{2}} \sum W i, t^{3}\right] /\left[(n-1)(n-2)\left(\sum W i, t^{2}\right)^{\frac{3}{2}}\right],
$$

where $n$ is the annual trading week of stock $i$. The greater the value of NCSKEW is, the higher the negative degree of skewness coefficient is, the greater the stock price crash risk.

Indicator 2: Down and up volatility ratio of returns (DUVOL)

$$
\text { DUVOL } i, t=\log \left\{\left[\left(n_{u}-1\right) \sum_{\mathrm{DOWN}} W i, t^{2}\right] /\left[\left(n_{d}-1\right) \sum_{\mathrm{UP}} W i, t^{2}\right]\right\},
$$

where the sample is divided into a rising period UP and a falling period DOWN according to whether the $W i, t$ is greater than (less than) the annual average rate of return, $n_{u}\left(n_{d}\right)$ is the number of up (down) weeks of stock $i$. A higher value of DUVOL indicates greater stock price crash risk.

\subsection{CSR Information Disclosure Measures}

CSR is the main independent variable. With the methods of existing literature for reference [9], the paper uses the following indicators to measure CSR: (1) Set dummy variable CSR1 to measure whether the company discloses the CSR information or not. If the company publish the CSR reports in the year, the value CSR1 is 1, and vice versa 0; (2) CSR disclosure level (CSR2) is measured by the logarithm of the CSR report score released by RKS. The higher the CSR2 is, the higher the information disclosure level of the CSR report is; (3) The motivations of CSR disclosure are classified as mandatory disclosure (CSRMAN), semi-mandatory disclosure (CSRSEMI), and voluntary disclosure (CSRVOL). More specifically, the CSR reports disclosed by the listed companies of "Shanghai Corporate Governance Sector" and companies issuing foreign listed foreign shares in the Shanghai Stock Exchange, and companies of "Shenzhen Stock Exchange Index 100" are defined as mandatory disclosure, since they are forced to disclose CSR reports by CSRC. Besides, the CSR reports of the central enterprise controlled by the SASAC are denoted as semi-mandatory disclosure, while the rest is classified as voluntary disclosure. Since RKS selects the annual CSR reports and sustainable reports disclosed by the A-share listed companies in Shanghai and Shenzhen, CSR reports in our research mainly refers to the CSR reports and sustainable reports. 


\subsection{Corporate Governance Factor Measures}

The two corporate governance regulatory variables are academic independent director and institutional ownership. Academic independent directors refer to independent directors who have been engaged in research work for a long time in universities, scientific research institutions and other academic institutions during the tenure. According to the existing literature [48,50], the academic independent directors studied in this paper mainly include business-type and expert-type. We identify keywords to screen the resume information of independent directors, and exclude visiting professors, honorary professors, and part-time professors. The indicator ACA calculation method is the ratio of academic independent directors to all independent directors. Referring to the method of Wang et al. [55], since institutional investors mainly include funds, securities traders, QFIIs, brokerage of financial products, social insurance funds, insurance companies, finance companies, banks, supplementary pension, trust companies, and non-financial listed companies, the ratio of the number of institutional ownership (excluding general corporate shareholdings) to the number of shares in circulation is used to measure institutional ownership (INST).

Besides, referring to existing literature [13,30], we control some variables that may affect the stock price crash risk and annual and industry fixed effects. In order to alleviate the time lag effect of variables on the stock price crash risk and endogenous problem, the explanatory variables and the control variables all adopt the value of lag period. Table 1 shows the definition and specific measurement of variables.

Table 1. Definition and metric of variables.

\begin{tabular}{|c|c|c|}
\hline Variable Name & Symbol & Metric Method \\
\hline Negative conditional skewness & NCSKEW & Equations (2) \\
\hline Down and up volatility ratio & DUVOL & Equations (3) \\
\hline $\begin{array}{l}\text { Whether to disclose Corporate Social } \\
\text { Responsibility (CSR) }\end{array}$ & CSR1 & The value is 1 if the CSR report is disclosed, otherwise 0 \\
\hline CSR disclosure level & CSR2 & The logarithm of the CSR report score evaluated by RKS \\
\hline Academic independent director & ACA & $\begin{array}{c}\text { Number of academic independent directors/number of } \\
\text { independent directors }\end{array}$ \\
\hline Institutional investor & INST & Shareholding ratio of institutional investors \\
\hline Weekly firm-specific yield & RET & Annual average weekly firm-specific yield \\
\hline Standard deviation of yield & SIGMA & Standard deviation of annual average weekly firm-specific yield \\
\hline Excess turnover rate & TURN & $\begin{array}{c}\text { The average monthly turnover rate difference between the year and the } \\
\text { previous year }\end{array}$ \\
\hline Firm size & SIZE & LN (year-end total assets) \\
\hline Asset-liability ratio & LEV & Total liabilities/total assets \\
\hline Total return on assets & ROA & Net profit in the year/total assets in the previous year \\
\hline Market-to-book ratio & MB & The ratio of total market value to book value \\
\hline Information transparency & ABACC & $\begin{array}{c}\text { Absolute value of actionable accrued profits calculated by the modified } \\
\text { Jones model }\end{array}$ \\
\hline
\end{tabular}

\subsection{Empirical Model}

The paper constructs multiple regression models and uses the software IBM SPSS Statistics 20 to examine our hypotheses. First, model (4) is established to test the effect of CSR disclosure on stock price crash risk (H1), and model (5) is established to test $\mathrm{H} 3$ and H4. Subsample regression of voluntary disclosure (CSRVOL), semi-compulsory disclosure (CSRSEMI) and compulsory disclosure (CSRMAN) is performed respectively to test $\mathrm{H} 2$.

$$
\begin{gathered}
\text { CrashRisk }_{i, t}=\alpha_{0}+\alpha_{1} \text { CSR }_{i, t-1}+\alpha_{2} \text { CSRsq }_{i, t-1}+\alpha_{3} \text { ControlVariables }_{i, t-1}+\varepsilon_{i, t-1} \\
\text { CrashRisk }_{i}=\gamma_{0} \begin{array}{r}
+\gamma_{1} \text { CSR }_{i, t-1} \\
+\gamma_{2} \text { CSRsq }_{i, t-1}+\gamma_{3} \text { FACTOR }_{i, t-1} \\
+\gamma_{4} \text { FACTOR }_{i, t-1}
\end{array}
\end{gathered}
$$

In the model, CSR is measured by CSR2. If $\alpha_{2}$ is significantly negative, H1 is established. We also examine the impact of CSR1 on the stock price crash risk. FACTOR takes ACA and INST respectively to test the moderating effect of the two corporate governance factors on the relationship between 
CSR and stock price crash risk. Also, we examine the differences in the above effects under different disclosure motivations through the subsample regression. The ControlVariables include RET, SIGMA, TURN, SIZE, LEV, ROA, MB and ABACC.

\section{Empirical Results}

\subsection{Descriptive Statistics}

The descriptive statistics of the full sample are shown in Table 2. During 2010-2015, the average values of NCSKEW and DUVOL are -0.279 and -0.185 , and the standard deviations are 0.671 and 0.464 respectively, indicating that there are significant differences in the stock price crash risk levels among companies. The average value of CSR 1 is 0.255 , indicating that about $25.5 \%$ of companies have released CSR reports during the period. The standard deviation of CSR2 is 1.577, indicating that the CSR information disclosure levels between samples are quite different.

Table 2. Descriptive statistics.

\begin{tabular}{ccccccc}
\hline Variable & $\mathbf{N}$ & Mean & Median & Minimum & Maximum & St. Dev \\
\hline NCSKEW & 6928 & -0.279 & -0.228 & -2.323 & 1.508 & 0.671 \\
DUVOL & 6928 & -0.185 & -0.180 & -1.373 & 0.967 & 0.464 \\
CSR1 & 6928 & 0.255 & 0.000 & 0.000 & 1.000 & 0.436 \\
CSR2 & 6928 & 0.918 & 0.000 & 0.000 & 4.460 & 1.577 \\
INST & 6928 & 9.828 & 4.920 & 0.000 & 57.022 & 12.389 \\
ACA & 4680 & 0.513 & 0.500 & 0.000 & 1.000 & 0.308 \\
RET & 6928 & -0.002 & -0.001 & -0.007 & 0.000 & 0.001 \\
SIGMA & 6928 & 0.051 & 0.047 & 0.018 & 0.122 & 0.021 \\
TURN & 6928 & -0.091 & -0.030 & -1.824 & 0.882 & 0.445 \\
SIZE & 6928 & 3.626 & 3.452 & 1.328 & 7.228 & 1.234 \\
LEV & 6928 & 0.444 & 0.444 & 0.049 & 0.879 & 0.215 \\
ROA & 6928 & 0.045 & 0.040 & -0.120 & 0.208 & 0.050 \\
MB & 6928 & 2.557 & 1.965 & 0.912 & 10.994 & 1.815 \\
ABACC & 6928 & 0.074 & 0.051 & 0.001 & 0.396 & 0.075 \\
\hline
\end{tabular}

In order to further observe whether there is a significant difference in the level of stock price crash risk between companies that disclose CSR information and the rest of companies, we provide the frequency table for CSR1 (Table 3) and results of the independent-samples t-test (Table 4).

Table 3. Frequency table for CSR1.

\begin{tabular}{cccccc}
\hline & & Frequency & Percentage & Valid Percentage & Accumulative Percentage \\
\hline \multirow{3}{*}{ Valid } & 0 & 5163 & 74.500 & 74.500 & 74.500 \\
& 1 & 1765 & 25.500 & 25.500 & 100 \\
& Total & 6928 & 100 & 100 & \\
\hline
\end{tabular}

Table 4. Results of the independent-samples t-test.

\begin{tabular}{ccccccc}
\hline & & Levene Test of Variance Equation & \multicolumn{3}{c}{ T test of Mean Value Equation } \\
& & F & Sig. & t & df & Sig. (Bilateral) \\
\hline \multirow{2}{*}{ NCSKEW } & Equal variances assumed & 0.022 & 0.883 & $-5.713^{* * *}$ & 6926.000 \\
\multirow{2}{*}{ DUVOL } & Equal variances not assumed & & & -5.000 & \\
& Equal variances assumed & 0.020 & 0.888 & $-6.824^{* * *}$ & 3068.254 & 0.000 \\
& Equal variances not assumed & & & $-6.809^{* * *}$ & 3041.933 & 0.000 \\
\hline
\end{tabular}

Notes: ${ }^{* * *}$ indicate statistical significance at the $1 \%$ level. 
Table 3 indicates that $74.5 \%$ of companies did not publish CSR reports in the sample period while the rest did. The t-test values in Table 4 shows that there is a significant difference in stock price crash risk among listed companies that have released CSR reports and the rest. And that's the reason why we need to further explore the relationship between CSR1 and stock price crash risk.

\subsection{Correlation Test}

The correlation test is conducted to avoid the collinearity of the main variables, which is shown in Table 5. The correlation coefficient between NCSKEW and DUVOL is 0.887 , indicating that they have good consistency. The correlation coefficients between SYNCH and CSR1, CSR2 are negative. It can be preliminarily judged that CSR information disclosure is negatively related to the stock price crash risk. But it remains to be further examined. The correlation coefficient between RET and SIGMA is -0.972 , and the absolute value is close to 1 . One of them should be deleted in the model, since there is obvious collinearity (according to the result of the latter, we finally delete RET). The correlation coefficients between the other variables are less than 0.550 , so it can be judged that there is no collinearity problem.

Table 5. Correlation matrix.

\begin{tabular}{|c|c|c|c|c|c|c|c|c|c|c|c|c|c|c|}
\hline & NCSKEW & DUVOL & CSR & LNRKS & RET & SIGMA & TURN & SIZE & LEV & ROA & MB & ABACC & INST & ACA \\
\hline NCSKEW & 1 & & & & & & & & & & & & & \\
\hline DUVOL & 0.877 & 1 & & & & & & & & & & & & \\
\hline CSR1 & -0.068 & -0.082 & 1 & & & & & & & & & & & \\
\hline RET & -0.033 & -0.017 & 0.157 & 0.156 & 1 & & & & & & & & & \\
\hline SIGMA & 0.049 & 0.033 & -0.183 & -0.182 & -0.972 & 1 & & & & & & & & \\
\hline TURN & -0.062 & -0.069 & 0.105 & 0.110 & -0.294 & 0.292 & 1 & & & & & & & \\
\hline SIZE & -0.121 & -0.150 & 0.457 & 0.474 & 0.199 & -0.238 & 0.198 & 1 & & & & & & \\
\hline MB & 0.112 & 0.096 & -0.175 & -0.177 & -0.536 & 0.542 & 0.024 & -0.448 & -0.394 & 0.290 & 1 & & & \\
\hline ABACC & 0.023 & 0.025 & -0.046 & -0.049 & 0.010 & -0.002 & -0.028 & -0.007 & 0.100 & 0.020 & 0.008 & 1 & & \\
\hline INST & 0.156 & 0.137 & 0.043 & 0.042 & -0.055 & 0.067 & -0.089 & 0.075 & -0.093 & 0.348 & 0.223 & 0.034 & 1 & \\
\hline ACA & 0.000 & 0.005 & 0.053 & 0.056 & 0.016 & -0.007 & -0.010 & 0.034 & 0.001 & 0.016 & -0.004 & -0.002 & 0.037 & 1 \\
\hline
\end{tabular}

\subsection{Regression Analysis}

\subsubsection{Regression Results for $\mathrm{H} 1$}

According to the results of the Hausman test, this paper finally selected the fixed effect model. The test results are shown in Table 6 (according to the $P=0.037$, the null hypothesis is rejected at $5 \%$ confidence level). At first, we have examined the impact of CSR1 on the stock price crash risk due to significant differences in companies that have issued and not released CSR reports. The results in Table 6 show that when the stock price crash risk is measured by NCSKEW and DUVOL respectively, the coefficient of CSR1 is negative but not significant, that is, the impact of CSR1 on the stock price crash risk is not significant. This indicates that investors may pay more attention to the information quality and level of CSR reports rather than whether they are published or not.

Also, the results in Table 6 indicate that there is no significant linear relationship between CSR information disclosure level index CSR2 and stock price crash risk. To this end, we further explore the nonlinear relationship between CSR2 and stock price crash risk.

Table 7 shows the regression results for the model (4). The regression results show that the coefficient of CSR2 is significantly positive, while the coefficient of squared CSR2sq is significantly negative, indicating that there is an inverse U-shaped nonlinear relationship between CSR2 and stock price crash risk. When the stock price crash risk is measured by NCSKEW (DUVOL), the inflection point obtained by mathematical method is CRS2 $=3.696($ CSR2 $=3.684)$. It shows that when the level of CSR2 is low, the increase of the CSR information disclosure level will aggravate the stock price crash risk, but as CSR2 increases above the threshold, the increase of the CSR information disclosure level will help to reduce the stock price crash risk, which is consistent with H1. When the CSR information disclosure level is low, CSR is more used as a self-interest tool for management, which will damage the information transparency and increase the stock price crash risk. As CSR information disclosure level 
increases to a certain level and is more in line with the long-term sustainable development strategy, the information asymmetry between the company and external investors will be alleviated, making the stock price closer to the firm's intrinsic value, and reducing the stock price crash risk. The coefficients of other control variables show that SIGMA, ROA and MB are positively correlated with stock price crash risk, which is consistent with the results of Kim et al. [13] and Wang et al. [4].

Table 6. Regression results of CSR and stock price crash risk.

\begin{tabular}{|c|c|c|c|c|}
\hline \multirow{2}{*}{ Variable } & \multicolumn{2}{|c|}{ Full Sample } & \multicolumn{2}{|c|}{ Disclosed Sample } \\
\hline & NCSKEW & DUVOL & NCSKEW & DUVOL \\
\hline \multirow{2}{*}{ CSR1 } & -0.029 & -0.022 & \multirow{2}{*}{-} & \multirow{2}{*}{ - } \\
\hline & $(-1.402)$ & $(-1.543)$ & & \\
\hline \multirow{2}{*}{ CSR2 } & \multirow{2}{*}{-} & \multirow{2}{*}{-} & 0.025 & 0.013 \\
\hline & & & $(0.376)$ & $(0.288)$ \\
\hline \multirow{2}{*}{ SIGMA } & $2.773^{* * *}$ & $1.708^{* * *}$ & 2.000 & 0.816 \\
\hline & $(4.830)$ & $(4.303)$ & $(1.514)$ & $(0.888)$ \\
\hline \multirow{2}{*}{ TURN } & $-0.040 *$ & -0.022 & 0.057 & 0.050 \\
\hline & $(-1.906)$ & $(-1.487)$ & $(0.868)$ & (1.096) \\
\hline \multirow{2}{*}{ SIZE } & -0.007 & $-0.021^{* * *}$ & -0.022 & $-0.029^{* *}$ \\
\hline & $(-0.679)$ & $(-3.050)$ & $(-1.193)$ & $(-2.309)$ \\
\hline \multirow{2}{*}{ LEV } & -0.082 & -0.056 & 0.136 & 0.104 \\
\hline & $(-1.537)$ & $(-1.502)$ & (1.135) & (1.253) \\
\hline \multirow{2}{*}{ ROA } & $0.826^{* * *}$ & $0.602^{* * *}$ & $1.241^{* * * *}$ & $0.907^{* * *}$ \\
\hline & $(4.291)$ & $(4.522)$ & (3.191) & (3.352) \\
\hline \multirow{2}{*}{ MB } & $0.018^{* * *}$ & 0.005 & $0.047^{* * *}$ & $0.023 *$ \\
\hline & $(2.739)$ & $(1.053)$ & $(2.753)$ & $(1.921)$ \\
\hline \multirow{2}{*}{ ABACC } & 0.113 & 0.062 & -0.352 & -0.171 \\
\hline & $(1.016)$ & $(0.809)$ & $(-1.471)$ & $(-1.027)$ \\
\hline \multirow{2}{*}{ Intercept } & $-0.871^{* * *}$ & $-0.499 * * *$ & $-1.326^{* * *}$ & $-0.766^{* * *}$ \\
\hline & $(-10.574)$ & $(-8.762)$ & $(-4.949)$ & $(-4.112)$ \\
\hline YEAR & YES & YES & YES & YES \\
\hline INDUSTRY & YES & YES & YES & YES \\
\hline $\mathrm{N}$ & 6927 & 6927 & 1764 & 1764 \\
\hline $\mathrm{F}$ & $14.151^{* * *}$ & $14.541^{* * *}$ & $6.286^{* * *}$ & $6.554^{* * *}$ \\
\hline Adj-R ${ }^{2}$ & 0.050 & 0.052 & 0.075 & 0.078 \\
\hline \multicolumn{2}{|c|}{ Hausman Test } & Chi-square statistic & Chi-square d.f. & Prob > chi 2 \\
\hline \multicolumn{2}{|c|}{ Ho: Difference in coefficients not systematic } & $17.840^{* *}$ & 9 & 0.037 \\
\hline
\end{tabular}

Notes: The values in brackets are $\mathrm{t}$-values, ${ }^{* * *},{ }^{* *}$, and ${ }^{*}$ indicate statistical significance at the $1 \%, 5 \%$, and $10 \%$ level, respectively. 
Table 7. Nonlinear regression results of CSR and stock price crash risk (H1).

\begin{tabular}{|c|c|c|}
\hline \multirow{2}{*}{ Variable } & \multicolumn{2}{|c|}{ Disclosed Sample } \\
\hline & NCSKEW & DUVOL \\
\hline CSR2 & $\begin{array}{c}2.506^{* *} \\
(2.373)\end{array}$ & $\begin{array}{l}1.584^{* *} \\
(2.157)\end{array}$ \\
\hline CSR2sq & $\begin{array}{l}-0.339^{* *} \\
(-2.354)\end{array}$ & $\begin{array}{c}-0.215^{* *} \\
(-2.143)\end{array}$ \\
\hline SIGMA & $\begin{array}{c}2.114 \\
(1.601)\end{array}$ & $\begin{array}{c}0.888 \\
(0.967)\end{array}$ \\
\hline TURN & $\begin{array}{c}0.053 \\
(0.812)\end{array}$ & $\begin{array}{c}0.048 \\
(1.045)\end{array}$ \\
\hline SIZE & $\begin{array}{c}-0.016 \\
(-0.890)\end{array}$ & $\begin{array}{l}-0.026^{* *} \\
(-2.025)\end{array}$ \\
\hline LEV & $\begin{array}{c}0.124 \\
(1.041)\end{array}$ & $\begin{array}{c}0.097 \\
(1.167)\end{array}$ \\
\hline ROA & $\begin{array}{c}1.199 * * * \\
(3.083)\end{array}$ & $\begin{array}{c}0.880 * * * \\
(3.253)\end{array}$ \\
\hline MB & $\begin{array}{c}0.047^{* * *} \\
(2.772)\end{array}$ & $\begin{array}{l}0.023 * \\
(1.937)\end{array}$ \\
\hline ABACC & $\begin{array}{c}-0.364 \\
(-1.522)\end{array}$ & $\begin{array}{c}-0.178 \\
(-1.073)\end{array}$ \\
\hline Intercept & $\begin{array}{c}-5.866^{* * * *} \\
(-3.013)\end{array}$ & $\begin{array}{c}-3.640 * * * \\
(-2.688)\end{array}$ \\
\hline YEAR & YES & YES \\
\hline INDUSTRY & YES & YES \\
\hline $\mathrm{N}$ & 1764 & 1764 \\
\hline $\mathrm{F}$ & $6.275^{* * *}$ & $6.497^{* * *}$ \\
\hline Adj- $R^{2}$ & 0.077 & 0.080 \\
\hline
\end{tabular}

Notes: The values in brackets are t-values, ${ }^{* * *},{ }^{* *}$, and ${ }^{*}$ indicate statistical significance at the $1 \%, 5 \%$, and $10 \%$ level, respectively.

\subsubsection{Regression Results for $\mathrm{H} 2$}

We divide the companies that have disclosed CSR reports into subsamples of mandatory, semi-mandatory, and voluntary disclosure to test the impact of disclosure motivations on the stock price crash risk. The results in Table 8 indicate that the coefficients of CSR2 and CSR2sq in mandatory disclosure sample are significantly positive and negative respectively, which are consistent with the results in Table 7. However, there is no significant non-linear relationship in semi-mandatory and voluntary disclosure samples. That is to say, under different disclosure motivations, CSR information disclosure has a different impact on the stock price crash risk, assuming $\mathrm{H} 2$ is valid.

Relatively speaking, the quality of CSR reports disclosed under the mandatory regulations of laws and regulations is higher. In order to maintain a good reputation, attract investors and avoid large penalty costs, the management has the incentive to improve the information disclosure quality and reduce bad news hoarding activities. The stock price crash risk will decrease since more objective and true CSR information is compulsively disclosed. However, there are also low-level CSR reports containing more formal and general information, which cannot fully exploit negative news inside the company and may increase the stock price crash risk. Therefore, there is still an inverse U-shaped nonlinear relationship between CSR2 and stock price crash risk in the mandatory sample. However, semi-mandatory and voluntary disclosure companies may improve the quality of information disclosure due to ethical awareness, but may also actively control CSR reports to obtain private benefits. If the CSR report reveals more positive information, the bad news hoarding activities of the management cannot be effectively supervised and thus cannot have a significant effect on the stock price crash risk. 
Table 8. Regression results of CSR, disclosure motivation and stock price crash risk (H2).

\begin{tabular}{ccccccc}
\hline \multirow{2}{*}{ Variable } & \multicolumn{2}{c}{ Mandatory } & \multicolumn{2}{c}{ Semi-Mandatory } & \multicolumn{2}{c}{ Voluntary } \\
\cline { 2 - 6 } & NCSKEW & DUVOL & NCSKEW & DUVOL & NCSKEW & DUVOL \\
\hline \multirow{2}{*}{ CSR2 } & $2.904^{* *}$ & $1.833^{* *}$ & 8.477 & 2.746 & 0.424 & 0.161 \\
& $(2.385)$ & $(2.130)$ & $(1.004)$ & $(0.505)$ & $(0.176)$ & $(0.097)$ \\
CSR2sq & $-0.398^{* *}$ & $-0.251^{* *}$ & -1.188 & -0.416 & -0.055 & -0.023 \\
& $(-2.413)$ & $(-2.148)$ & $(-1.032)$ & $(-0.561)$ & $(-0.164)$ & $(-0.100)$ \\
SIGMA & $3.561^{* *}$ & 0.500 & -2.231 & -2.622 & 1.704 & 2.004 \\
& $(1.984)$ & $(0.394)$ & $(-0.444)$ & $(-0.811)$ & $(0.747)$ & $(1.284)$ \\
TURN & 0.056 & 0.102 & 0.431 & 0.234 & 0.012 & 0.008 \\
& $(0.551)$ & $(1.419)$ & $(1.567)$ & $(1.319)$ & $(0.127)$ & $(0.114)$ \\
SIZE & -0.008 & -0.022 & -0.043 & 0.055 & -0.011 & -0.015 \\
& $(-0.335)$ & $(-1.352)$ & $(-0.370)$ & $(0.745)$ & $(-0.288)$ & $(-0.588)$ \\
LEV & $0.272^{*}$ & $0.237^{* *}$ & 0.622 & 0.274 & -0.129 & -0.155 \\
ROA & $(1.762)$ & $(2.175)$ & $(1.108)$ & $(0.758)$ & $(-0.575)$ & $(-1.015)$ \\
& $0.953^{*}$ & $0.820^{* *}$ & $4.445^{* * *}$ & $2.546 * *$ & 1.061 & 0.771 \\
MB & $(1.905)$ & $(2.320)$ & $(2.642)$ & $(2.350)$ & $(1.457)$ & $(1.546)$ \\
& $0.059^{* * *}$ & $0.038^{* *}$ & 0.092 & 0.059 & 0.038 & 0.007 \\
ABACC & $(2.585)$ & $(2.351)$ & $(1.143)$ & $(1.133)$ & $(1.297)$ & $(0.338)$ \\
& $-0.626^{*}$ & $-0.411^{*}$ & $2.122 * *$ & $1.222 * *$ & -0.566 & -0.246 \\
Intercept & $(-1.842)$ & $(-1.711)$ & $(2.439)$ & $(2.181)$ & $(-1.406)$ & $(-0.891)$ \\
YEAR & $-6.693^{* * *}$ & $-4.127^{* *}$ & -17.057 & $-5.733 * *$ & -1.892 & -1.007 \\
INDUSTRY & $(-2.959)$ & $(-2.580)$ & $(-1.096)$ & $(-0.572)$ & $(-0.433)$ & $(-0.337)$ \\
N & YES & YES & YES & YES & YES & YES \\
F & 1034 & YES & YES & YES & YES & YES \\
Adj-R ${ }^{2}$ & $4.618^{* * *}$ & $4.435^{* * *}$ & $1.994 * *$ & $2.227 * * *$ & $2.390 * * *$ & $2.787 * * *$ \\
\hline Not & 0.086 & 0.082 & 0.136 & 0.163 & 0.055 & 0.070 \\
\hline
\end{tabular}

Notes: The values in brackets are t-values, ${ }^{* * *},{ }^{* *}$, and ${ }^{*}$ indicate statistical significance at the $1 \%, 5 \%$, and $10 \%$ level, respectively.

\subsubsection{Regression Results for $\mathrm{H} 3$}

Further, we examine the role of the internal supervisor in regulating the relationship between CSR and stock price crash risk. Since the test results of $\mathrm{H} 1$ and $\mathrm{H} 2$ show that there is an inverted U-shaped relationship between CSR information disclosure and stock price crash risk in the disclosed and mandatory disclosure samples, we examined the role of adjustment factors in these two samples.

Table 9 shows the results for H3. In the sample of disclosed CSR information, the coefficient of the cross-term $A C A^{*} \mathrm{CSR} 2$ is significantly positive, indicating that the academic independent director (ACA) will aggravate the positive correlation between CSR2 and the stock price crash risk, and weaken the negative correlation between the two. However, there isn't such effect in the mandatory disclosure sample.

The above results partially verify the $\mathrm{H} 3$. Due to the lack of commercial practice experience and energy, the academic independent director in China cannot effectively participate in corporate affairs, and cannot fully play the supervisory role. The lack of responsibility further exacerbates the information asymmetry between the internal management and external investors of the company. Especially there is a general concentration of equity in China, independent directors are likely to be controlled by major shareholders and passively perform their duties. Independent directors may seek short-term interests by collusion with management to hide bad news inside the company. Such short-sighted behavior seriously damages the interests of small and medium-sized shareholders, and further increased the future stock price crash risk, that is, academic independent directors have a positive moderating effect on the relationship between CSR2 and stock price crash risk. 
Table 9. Regression results of CSR, academic independent director and stock price crash risk (H3).

\begin{tabular}{|c|c|c|c|c|}
\hline \multirow{2}{*}{ Variable } & \multicolumn{2}{|c|}{ Disclosed Sample } & \multicolumn{2}{|c|}{ Mandatory Sample } \\
\hline & NCSKEW & DUVOL & NCSKEW & DUVOL \\
\hline CSR2 & $\begin{array}{c}2.433 \text { ** } \\
(1.967)\end{array}$ & $\begin{array}{c}1.395 \\
(1.628)\end{array}$ & $\begin{array}{l}2.920 \text { ** } \\
(2.000)\end{array}$ & $\begin{array}{l}1.857 * \\
(1.815)\end{array}$ \\
\hline CSR2sq & $\begin{array}{l}-0.359 * * \\
(-2.083)\end{array}$ & $\begin{array}{l}-0.206 \text { * } \\
(-1.728)\end{array}$ & $\begin{array}{l}-0.413^{* *} \\
(-2.027)\end{array}$ & $\begin{array}{l}-0.270 \text { * } \\
(-1.893)\end{array}$ \\
\hline ACA & $\begin{array}{l}-1.628 * * \\
(-1.980)\end{array}$ & $\begin{array}{c}-0.874 \\
(-1.536)\end{array}$ & $\begin{array}{c}-0.568 \\
(-0.561)\end{array}$ & $\begin{array}{c}-0.539 \\
(-0.759)\end{array}$ \\
\hline CSR2*ACA & $\begin{array}{c}0.458 * * \\
(1.988)\end{array}$ & $\begin{array}{l}0.266 * \\
(1.666)\end{array}$ & $\begin{array}{c}0.182 \\
(0.644)\end{array}$ & $\begin{array}{c}0.194 \\
(0.981)\end{array}$ \\
\hline SIGMA & $\begin{array}{l}3.263^{* *} \\
(2.061)\end{array}$ & $\begin{array}{c}1.560 \\
(1.423)\end{array}$ & $\begin{array}{l}4.375^{* *} \\
(2.099)\end{array}$ & $\begin{array}{c}1.479 \\
(1.012)\end{array}$ \\
\hline TURN & $\begin{array}{c}-0.018 \\
(-0.227)\end{array}$ & $\begin{array}{c}-0.001 \\
(-0.013)\end{array}$ & $\begin{array}{l}-0.055 \\
(-0.448)\end{array}$ & $\begin{array}{c}-0.014 \\
(-0.159)\end{array}$ \\
\hline SIZE & $\begin{array}{c}-0.017 \\
(-0.761)\end{array}$ & $\begin{array}{c}-0.020 \\
(-1.245)\end{array}$ & $\begin{array}{c}-0.025 \\
(-0.881)\end{array}$ & $\begin{array}{c}-0.023 \\
(-1.180)\end{array}$ \\
\hline LEV & $\begin{array}{c}0.103 \\
(0.722)\end{array}$ & $\begin{array}{c}0.081 \\
(0.817)\end{array}$ & $\begin{array}{c}0.378^{* *} \\
(2.072)\end{array}$ & $\begin{array}{c}0.278 * * \\
(2.176)\end{array}$ \\
\hline ROA & $\begin{array}{l}1.071 \text { ** } \\
(2.321)\end{array}$ & $\begin{array}{c}0.875^{* * *} \\
(2.738)\end{array}$ & $\begin{array}{c}0.699 \\
(1.181)\end{array}$ & $\begin{array}{c}0.618 \\
(1.490)\end{array}$ \\
\hline MB & $\begin{array}{c}0.060 * * * \\
(2.921)\end{array}$ & $\begin{array}{c}0.033^{* *} \\
(2.343)\end{array}$ & $\begin{array}{c}0.085^{* * *} \\
(3.216)\end{array}$ & $\begin{array}{c}0.055^{* * *} \\
(2.950)\end{array}$ \\
\hline ABACC & $\begin{array}{l}-0.605^{* *} \\
(-2.096)\end{array}$ & $\begin{array}{c}-0.320 \\
(-1.602)\end{array}$ & $\begin{array}{l}-0.934^{* *} \\
(-2.354)\end{array}$ & $\begin{array}{l}-0.530 \text { * } \\
(-1.908)\end{array}$ \\
\hline Intercept & $\begin{array}{l}-5.403^{* *} \\
(-2.395)\end{array}$ & $\begin{array}{l}-3.154^{* *} \\
(-2.019)\end{array}$ & $\begin{array}{l}-6.593 * * \\
(-2.482)\end{array}$ & $\begin{array}{l}-4.062 * * \\
(-2.182)\end{array}$ \\
\hline YEAR & YES & YES & YES & YES \\
\hline INDUSTRY & YES & YES & YES & YES \\
\hline $\mathrm{N}$ & 1275 & 1275 & 768 & 768 \\
\hline $\mathrm{F}$ & $5.200 * * *$ & $5.032 * * *$ & $3.761^{* * *}$ & $3.661 * * *$ \\
\hline $\operatorname{Adj}-R^{2}$ & 0.090 & 0.087 & 0.094 & 0.091 \\
\hline
\end{tabular}

Notes: The values in brackets are t-values, ${ }^{* * *}, * *$, and ${ }^{*}$ indicate statistical significance at the $1 \%, 5 \%$, and $10 \%$ level, respectively.

\subsubsection{Regression Results for $\mathrm{H} 4$}

The regression results for $\mathrm{H} 4$ are shown in Table 10. In the disclosed sample and the mandatory sample, the coefficients of cross term CSR2*INST are negative and most of them are significant. The results indicate that institutional investors will weaken the positive effect of CSR information disclosure on the stock price crash risk, and strengthen the negative correlation between the two, that is, $\mathrm{H} 4$ is established. For listed companies in China, institutional investors can play an active external supervisory role on managers' bad news hoarding behavior, and urge management to improve the information disclosure quality of CSR reports. Such a monitoring mechanism will weaken the positive effect of CSR2 on the stock price crash risk and strengthen the negative effect of CSR2 on the crash risk, that is, the institutional investor has a negative adjustment effect on the relationship between CSR2 and stock price crash risk. 
Table 10. Regression results of CSR, institutional investor and stock price crash risk (H4).

\begin{tabular}{|c|c|c|c|c|}
\hline \multirow{2}{*}{ Variable } & \multicolumn{2}{|c|}{ Disclosed Sample } & \multicolumn{2}{|c|}{ Mandatory Sample } \\
\hline & NCSKEW & DUVOL & NCSKEW & DUVOL \\
\hline CSR2 & $\begin{array}{c}2.656^{* *} \\
(2.508)\end{array}$ & $\begin{array}{c}1.629 * * \\
(2.208)\end{array}$ & $\begin{array}{c}3.257 \text { ** } \\
(2.661)\end{array}$ & $\begin{array}{c}1.914^{* *} \\
(2.205)\end{array}$ \\
\hline CSR2sq & $\begin{array}{l}-0.340^{* *} \\
(-2.369)\end{array}$ & $\begin{array}{l}-0.211^{* *} \\
(-2.106)\end{array}$ & $\begin{array}{l}-0.422 * * \\
(-2.564)\end{array}$ & $\begin{array}{c}-0.253^{* *} \\
(-2.167)\end{array}$ \\
\hline INST & $\begin{array}{c}0.057^{* * *} \\
(3.177)\end{array}$ & $\begin{array}{c}0.031 \text { ** } \\
(2.483)\end{array}$ & $\begin{array}{c}0.065^{* * *} \\
(3.013)\end{array}$ & $\begin{array}{l}0.027 * \\
(1.772)\end{array}$ \\
\hline CSR2*INST & $\begin{array}{c}-0.014 * * * \\
(-2.767)\end{array}$ & $\begin{array}{l}-0.007^{* *} \\
(-2.100)\end{array}$ & $\begin{array}{c}-0.016^{* * *} \\
(-2.720)\end{array}$ & $\begin{array}{c}-0.006 \\
(-1.484)\end{array}$ \\
\hline SIGMA & $\begin{array}{c}1.649 \\
(1.256)\end{array}$ & $\begin{array}{c}0.572 \\
(0.625)\end{array}$ & $\begin{array}{l}3.205 * \\
(1.793)\end{array}$ & $\begin{array}{c}0.193 \\
(0.152)\end{array}$ \\
\hline TURN & $\begin{array}{c}0.047 \\
(0.720)\end{array}$ & $\begin{array}{c}0.045 \\
(0.980)\end{array}$ & $\begin{array}{c}0.022 \\
(0.215)\end{array}$ & $\begin{array}{c}0.085 \\
(1.183)\end{array}$ \\
\hline SIZE & $\begin{array}{l}-0.033 * \\
(-1.794)\end{array}$ & $\begin{array}{c}-0.036^{* * *} \\
(-2.819)\end{array}$ & $\begin{array}{c}-0.019 \\
(-0.836)\end{array}$ & $\begin{array}{l}-0.028 * \\
(-1.707)\end{array}$ \\
\hline LEV & $\begin{array}{c}0.161 \\
(1.353)\end{array}$ & $\begin{array}{c}0.118 \\
(1.428)\end{array}$ & $\begin{array}{l}0.285^{*} \\
(1.863)\end{array}$ & $\begin{array}{c}0.240 * * \\
(2.213)\end{array}$ \\
\hline ROA & $\begin{array}{c}0.807 \text { ** } \\
(2.055)\end{array}$ & $\begin{array}{c}0.625 * * \\
(2.284)\end{array}$ & $\begin{array}{c}0.475 \\
(0.931)\end{array}$ & $\begin{array}{c}0.509 \\
(1.405)\end{array}$ \\
\hline MB & $\begin{array}{l}0.032 * \\
(1.885)\end{array}$ & $\begin{array}{c}0.014 \\
(1.138)\end{array}$ & $\begin{array}{l}0.044 * \\
(1.931)\end{array}$ & $\begin{array}{l}0.029 * \\
(1.809)\end{array}$ \\
\hline ABACC & $\begin{array}{c}-0.351 \\
(-1.481)\end{array}$ & $\begin{array}{l}-0.168 \\
(-1.020)\end{array}$ & $\begin{array}{l}-0.561 * \\
(-1.662)\end{array}$ & $\begin{array}{c}-0.367 \\
(-1.536)\end{array}$ \\
\hline Intercept & $\begin{array}{c}-6.302 * * * \\
(-3.199)\end{array}$ & $\begin{array}{c}-3.795^{* * *} \\
(-2.765)\end{array}$ & $\begin{array}{c}-7.585^{* * *} \\
(-3.300)\end{array}$ & $\begin{array}{c}-4.341^{* * *} \\
(-2.663)\end{array}$ \\
\hline YEAR & YES & YES & YES & YES \\
\hline INDUSTRY & YES & YES & YES & YES \\
\hline $\mathrm{N}$ & 1764 & 1764 & 1034 & 1034 \\
\hline F & $7.144^{* * *}$ & $7.101^{* * *}$ & $5.060^{* * *}$ & $4.657^{* * *}$ \\
\hline $\operatorname{Adj}-R^{2}$ & 0.095 & 0.094 & 0.102 & 0.093 \\
\hline
\end{tabular}

Notes: The values in brackets are $\mathrm{t}$-values, ${ }^{* * *}, * *$, and ${ }^{*}$ indicate statistical significance at the $1 \%, 5 \%$, and $10 \%$ level, respectively.

\subsection{Robustness Test}

In order to ensure the reliability and validity of our results, the following robustness tests have been conducted: (1) NCSKEW and DUVOL are used to measure the stock price crash risk respectively, and the results maintain a good consistency (the regression results are shown in Tables 6-12); (2) Since the proportion of funds is highest among institutional investors, we use the ratio of shares held by the fund to the number of shares in circulation (INST2) as an alternative to the institutional investor. The results in Table 11 show that the cross-term CSR2*INST2 coefficient is significantly negative, assuming $\mathrm{H} 4$ is still established.

Table 11. Regression results of substituting institutional investor indicator $(\mathrm{H} 4)$.

\begin{tabular}{ccccc}
\hline \multirow{2}{*}{ Variable } & \multicolumn{2}{c}{ Disclosed Sample } & \multicolumn{2}{c}{ Mandatory Sample } \\
\cline { 2 - 5 } & NCSKEW & DUVOL & NCSKEW & DUVOL \\
\hline \multirow{2}{*}{ CSR2 } & $2.904^{* * *}$ & $1.689^{* *}$ & $3.256^{* * *}$ & $1.868^{* *}$ \\
& $(2.714)$ & $(2.263)$ & $(2.648)$ & $(2.144)$ \\
CSR2sq & $-0.371^{* *}$ & $-0.217^{* *}$ & $-0.422^{* *}$ & $-0.247^{* *}$ \\
& $(-2.558)$ & $(-2.147)$ & $(-2.552)$ & $(-2.103)$ \\
INST2 & $0.077^{* * *}$ & $0.043^{* * *}$ & $0.078^{* * *}$ & 0.031 \\
& $(3.389)$ & $(2.730)$ & $(2.748)$ & $(1.542)$ \\
CSR2*INST2 & $-0.019^{* * *}$ & $-0.010^{* *}$ & $-0.018^{* *}$ & -0.006 \\
& $(-2.940)$ & $(-2.300)$ & $(-2.361)$ & $(-1.144)$ \\
\hline
\end{tabular}


Table 11. Cont.

\begin{tabular}{ccccc}
\hline \multirow{2}{*}{ Variable } & \multicolumn{2}{c}{ Disclosed Sample } & \multicolumn{2}{c}{ Mandatory Sample } \\
\cline { 2 - 5 } & NCSKEW & DUVOL & NCSKEW & DUVOL \\
\hline \multirow{2}{*}{ SIGMA } & 1.324 & 0.329 & 2.203 & -0.666 \\
& $(0.984)$ & $(0.350)$ & $(1.192)$ & $(-0.509)$ \\
TURN & 0.042 & 0.041 & 0.032 & 0.087 \\
& $(0.625)$ & $(0.875)$ & $(0.313)$ & $(1.200)$ \\
SIZE & $-0.044^{* *}$ & $-0.043 * * *$ & -0.037 & $-0.040 * *$ \\
& $(-2.346)$ & $(-3.324)$ & $(-1.563)$ & $(-2.390)$ \\
LEV & 0.135 & 0.094 & $0.268^{*}$ & $0.214^{*}$ \\
& $(1.111)$ & $(1.107)$ & $(1.710)$ & $(1.930)$ \\
ROA & $0.810^{* *}$ & $0.578^{* *}$ & 0.489 & 0.442 \\
& $(2.004)$ & $(2.048)$ & $(0.925)$ & $(1.179)$ \\
MB & 0.022 & 0.008 & 0.031 & 0.022 \\
& $(1.235)$ & $(0.618)$ & $(1.301)$ & $(1.304)$ \\
ABACC & -0.378 & -0.185 & -0.568 & -0.389 \\
& $(-1.553)$ & $(-1.090)$ & $(-1.634)$ & $(-1.579)$ \\
Intercept & $-6.661^{* * *}$ & $-3.833 * * *$ & $-7.350 * * *$ & $-4.079 *$ \\
YEAR & $(-3.343)$ & $(-2.757)$ & $(-3.186)$ & $(-2.495)$ \\
INDUSTRY & YES & YES & YES & YES \\
N & YES & YES & YES & YES \\
F & 1721 & 1721 & 1016 & 1016 \\
Adj-R ${ }^{2}$ & $7.320 * * *$ & $7.438^{* * *}$ & $5.041^{* * *}$ & $4.828 * * *$ \\
& 0.099 & 0.101 & 0.103 & 0.099 \\
\hline
\end{tabular}

Notes: The values in brackets are t-values, ${ }^{* * *},{ }^{* *}$, and ${ }^{*}$ indicate statistical significance at the $1 \%, 5 \%$, and $10 \%$ level, respectively.

Table 12. Regression results of controlling endogeneity due to missing variables ( $\mathrm{H} 1$ and $\mathrm{H} 2)$.

\begin{tabular}{|c|c|c|c|c|}
\hline \multirow{2}{*}{ Variable } & \multicolumn{2}{|c|}{ Disclosed Sample } & \multicolumn{2}{|c|}{ Mandatory Sample } \\
\hline & NCSKEW & DUVOL & NCSKEW & DUVOL \\
\hline CSR2 & $2.456^{* *}$ & $1.528^{* *}$ & $2.940 * *$ & 1.809 ** \\
\hline CSR2sq & $\begin{array}{c}-0.332 * * \\
(-2.288)\end{array}$ & $\begin{array}{l}-0.207 * * \\
(-2.051)\end{array}$ & $\begin{array}{l}-0.403 * * \\
(-2.419)\end{array}$ & $\begin{array}{c}-0.248 \text { ** } \\
(-2.098)\end{array}$ \\
\hline SIGMA & $\begin{array}{c}2.072 \\
(1.565)\end{array}$ & $\begin{array}{c}0.885 \\
(0.961)\end{array}$ & $\begin{array}{l}3.526^{*} \\
(1.961)\end{array}$ & $\begin{array}{c}0.483 \\
(0.380)\end{array}$ \\
\hline TURN & $\begin{array}{c}0.057 \\
(0.859)\end{array}$ & $\begin{array}{c}0.047 \\
(1.035)\end{array}$ & $\begin{array}{c}0.060 \\
(0.594)\end{array}$ & $\begin{array}{c}0.100 \\
(1.395)\end{array}$ \\
\hline SIZE & $\begin{array}{c}-0.015 \\
(-0.788)\end{array}$ & $\begin{array}{l}-0.025 * \\
(-1.954)\end{array}$ & $\begin{array}{c}-0.003 \\
(-0.132)\end{array}$ & $\begin{array}{c}-0.019 \\
(-1.164)\end{array}$ \\
\hline LEV & $\begin{array}{c}0.127 \\
(1.056)\end{array}$ & $\begin{array}{c}0.098 \\
(1.177)\end{array}$ & $\begin{array}{l}0.267 * \\
(1.721)\end{array}$ & $\begin{array}{c}0.233 * * \\
(2.127)\end{array}$ \\
\hline ROA & $\begin{array}{c}1.192^{* * *} \\
(3.043)\end{array}$ & $\begin{array}{c}0.883^{* * *} \\
(3.241)\end{array}$ & $\begin{array}{l}0.936^{*} \\
(1.858)\end{array}$ & $\begin{array}{c}0.796^{* *} \\
(2.234)\end{array}$ \\
\hline MB & $\begin{array}{c}0.048^{* * *} \\
(2.764)\end{array}$ & $\begin{array}{l}0.022 * \\
(1.867)\end{array}$ & $\begin{array}{c}0.062 * * * \\
(2.710)\end{array}$ & $\begin{array}{l}0.040^{* *} \\
(2.444)\end{array}$ \\
\hline ABACC & $\begin{array}{c}-0.364 \\
(-1.516)\end{array}$ & $\begin{array}{c}-0.183 \\
(-1.093)\end{array}$ & $\begin{array}{l}-0.591 * \\
(-1.730)\end{array}$ & $\begin{array}{c}-0.395 \\
(-1.632)\end{array}$ \\
\hline DUALITY & $\begin{array}{c}0.018 \\
(0.410)\end{array}$ & $\begin{array}{c}0.003 \\
(0.090)\end{array}$ & $\begin{array}{l}-0.023 \\
(-0.385)\end{array}$ & $\begin{array}{l}-0.010 \\
(-0.225)\end{array}$ \\
\hline BOARD & $\begin{array}{c}-0.004 \\
(-0.473)\end{array}$ & $\begin{array}{c}-0.003 \\
(-0.420)\end{array}$ & $\begin{array}{l}-0.004 \\
(-0.415)\end{array}$ & $\begin{array}{c}-0.003 \\
(-0.396)\end{array}$ \\
\hline INDBOARD & $\begin{array}{l}-0.107 \\
(-0.365)\end{array}$ & $\begin{array}{c}0.049 \\
(0.242)\end{array}$ & $\begin{array}{l}-0.486 \\
(-1.256)\end{array}$ & $\begin{array}{c}-0.252 \\
(-0.919)\end{array}$ \\
\hline Intercept & $\begin{array}{c}-5.710^{* * *} \\
(-2.901)\end{array}$ & $\begin{array}{c}-3.536 * * * \\
(-2.582)\end{array}$ & $\begin{array}{c}-6.555^{* * *} \\
(-2.862)\end{array}$ & $\begin{array}{l}-3.967 * * \\
(-2.448)\end{array}$ \\
\hline YEAR & YES & YES & YES & YES \\
\hline INDUSTRY & YES & YES & YES & YES \\
\hline $\mathrm{N}$ & 1761 & 1761 & 1032 & 1032 \\
\hline F & $5.679 * * *$ & $5.867^{* * *}$ & $4.206^{* * *}$ & $4.008^{* * *}$ \\
\hline Adj- $R^{2}$ & 0.076 & 0.079 & 0.085 & 0.080 \\
\hline
\end{tabular}

Notes: The values in brackets are $t$-values, ${ }^{* * *}, * *$, and ${ }^{*}$ indicate statistical significance at the $1 \%, 5 \%$, and $10 \%$ level, respectively. 
Furthermore, the endogeneity problem is also a problem that needs to be alleviated. (1) There may exist causal relationships between CSR information disclosure and stock price crash risk. The logic of CSR information disclosure affecting the stock price crash risk has been discussed in the previous section. Conversely, the level of stock price crash risk can also affect the motivation and quality of CSR information disclosure by affecting the mentality and behavior of managers. To alleviate this endogeneity problem, we use the lagging CSR information disclosure indicators in all models; (2) In order to alleviate the endogenous problem caused by missing variables, this paper further adds three control variables according to the method of $\mathrm{Xu}$ et al. [56]. The three control variables are whether the chairman and general manager is harmony (DUALITY), the board size (BOARD) and the proportion of independent directors (INDBOARD). The regression results in Table 12 are consistent with the previous ones.

On the whole, after replacing the key indicators and controlling endogeneity, the results maintain a good consistency, which shows that the conclusions of this paper are reliable.

\section{Conclusions and Suggestions}

This paper examines the relationship between CSR information disclosure and stock price crash risk based on the sample of China Shanghai and Shenzhen A-share listed companies in 2010-2015 years. The results show that: (1) There is an inverted U-shaped nonlinear relationship between CSR information disclosure and stock price crash risk. That is, as the CSR information disclosure level increases, the CSR information disclosure first aggravates and then reduces the stock price crash risk; (2) under different disclosure motivations, there is a significant difference in the impact of CSR information disclosure on stock price crash risk. In the mandatory disclosure sample, there is still an inverted U-shaped relationship between CSR information disclosure and stock price crash risk, but not in the semi-mandatory sample and voluntary disclosure sample; (3) the academic independent director has a positive adjustment effect on the relationship between CSR2 and stock price crash risk, while the institutional investor has a negative adjustment effect on the relationship between CSR2 and stock price crash risk.

The research is of great significance for enriching existing research systems and understanding the role of CSR information disclosure: (1) The paper expands the research on the impact of CSR information disclosure, and makes a more detailed distinction between CSR information disclosure motivations, and puts internal and external corporate governance mechanisms under the same research framework. The results show that both internal independent directors and external institutional investors can influence the relationship between CSR information disclosure and stock price crash risk, which provides a new perspective for improving the information disclosure quality of listed companies and stabilizing capital market; (2) For investors, what really matters is the timeliness, sufficiency and objectivity of the information contained in CSR reports, rather than whether to issue CSR reports. Since there is an inverted U-shaped relationship between the CSR information disclosure and stock price crash risk, only by improving the quality of CSR information disclosure to a certain level can information asymmetry be alleviated and the stock price crash risk be reduced; (3) Mandatory disclosure has been proved to have a good corporate governance role in China. Legal enforcement can largely guarantee the quality of CSR information disclosure, thereby reducing the stock price crash risk. However, semi-compulsory and voluntary disclosure of CSR information cannot inhibit the stock price crash risk, which should be paid more attention to.

The results have the following policy implications: (1) When the level of CSR information disclosure is low, CSR reports are more used as self-interested tools for management, making it difficult to fully tap the negative information inside the company. In order to effectively improve the quality of corporate information disclosure and reduce the stock price crash risk, it is necessary to substantially supervise the information adequacy and objectivity of CSR reports and strengthen the objective third-party authentication, especially for semi-compulsory and voluntary disclosure of CSR information; (2) Academic independent directors occupy a considerable proportion of the independent 
directors of listed companies in China, but they have not fully exerted their supervisory role, and have not timely stopped and exposed the bad news hoarding behavior of management. China should further strengthen the independent review of independent directors through th legal system, selection and other means, and improve the enthusiasm of independent directors through salary incentives and reputation incentives; (3) Institutional investors in China play an important external supervisory role for listed companies. In order to further improve corporate governance and stabilize the capital market, institutional investors should be further regulated and guided to enhance the supervisory role in the future.

Although our research is of great theoretical and practical significance, there are still limitations. Firstly, the measuring method of variables should be further improved to ensure the reliability of the research. Because there is no unified non-financial indicator for the measurement of CSR at home and abroad, we use the logarithm of the CSR report score by RKS to measure the CSR level according to the existing domestic research. Although the score is relatively comprehensive and authoritative, there is a certain degree of subjectivity which needs to be improved.

Secondly, although the paper has carried out research from the perspective of internal and external subjects, there is no more comprehensive classification of independent directors and institutional investors. This paper also lacks systematic research on the role of other internal and external governance factors. In the future, further consideration may be given to the differences in the roles of different types of independent directors and institutional investors, as well as internal management rights, external media, institutional environment and other factors.

Author Contributions: The manuscript was written with the contributions of all authors. C.L. presents conceptualization, themes, methodology, project administration and funding acquisition, writes the first draft with J.D. and J.Q. J.D. conceived the theoretical part, designed empirical research and revised the paper. J.Q. take a lot of effort in the introduction, data collection, and formatting of papers.

Funding: The paper is supported by Fundamental Funds for Humanities and Social Sciences of Beijing Jiaotong University (2018JBW006).

Conflicts of Interest: The authors declare no conflict of interest.

\section{References}

1. Hutton, A.P.; Marcus, A.J.; Tehranian, H. Opaque Financial Reports, R2, and Crash Risk. J. Financ. Econ. 2009, 94, 67-86. [CrossRef]

2. Kothari, S.P.; Shu, S.; Wysocki, P.D. Do Managers Withhold Bad News? J. Account. Res. 2009, 47, $241-276$. [CrossRef]

3. Jin, L.; Myers, C.S. Around the World: New Theory and New Tests. J. Financ. Econ. 2006, 79, $257-292$. [CrossRef]

4. Wang, H.; Cao, F.; Ye, K. Monitoring or Tunneling? The Proportion of the Proportion Held by the Big Shareholders and the Risk of the Crash of the Stock Price. Manag. World 2015, 2, $45-57$.

5. Quan, X.; Xiao, H. Study on the Effect of Corporate Social Responsibility Disclosure on Stock Price Crash Risk Based on Mediation Mechanism of Accounting Conservatism. China Soft Sci. 2016, 06, 80-97.

6. Carroll, A. A Three-dimensional Conceptual Model of Corporate Performance. Acad. Manag. Rev. 1979, 4, 497-505. [CrossRef]

7. Clarkson, M.E. A Stakeholder Framework for Analyzing and Evaluating Corporate Social Performance. Acad. Manag. Rev. 1995, 20, 92-117. [CrossRef]

8. Jha, A.; Cox, J. Corporate Social Responsibility and Social Capital. J. Bank. Financ. 2015, 60, 252-270. [CrossRef]

9. Dutordoir, M.; Strong, N.; Sun, P. Corporate Social Responsibility and Seasoned Equity Offerings. J. Corp. Financ. 2018, 50, 158-179. [CrossRef]

10. Xu, J.; Liu, H. On the Corporate Social Responsibility Disclosure Practice to Central Enterprises: Evidence from 100 CSR Reports Between 2006 and 2010. J. Zhongnan Univ. Econ. Law 2010, 6, 77-84.

11. Dai, J.; Lu, C.; Yang, Y.; Zheng, Y. Is the Social Responsibility Information Disclosed by the Companies really Valuable?-Evidence from Chinese Stock Price Synchronicity. Sustainability 2018, 10, 3578. [CrossRef] 
12. Dhaliwal, D.; Li, O.; Tsang, A.; Yang, Y. Voluntary Nonfinancial Disclosure and the Cost of Equity Capital: The Initiation of Corporate Social Responsibility Reporting. Account. Rev. 2011, 86, 59-100. [CrossRef]

13. Kim, Y.; Li, H.; Li, S. Corporate Social Responsibility and Stock Price Crash Risk. J. Bank. Financ. 2014, 6, 1-13. [CrossRef]

14. Barnea, A.; Rubin, A. Corporate Social Responsibility as a Conflict Between Shareholders. J. Bus. Ethics 2010, 97, 71-86. [CrossRef]

15. Dahlsrud, A. How Corporate Social Responsibility Is Defined: An Analysis of 37 Definitions. Corp. Soc. Environ. Manag. 2008, 15, 1-13. [CrossRef]

16. Guidry, R.P.; Patten, D.M. Market Reactions the First-time Issuance of Corporate Sustainability Reports. Sustainability Accounting. Manag. Policy J. 2010, 1, 33-50.

17. Barnea, A.; Heinkel, R.; Kraus, A. Corporate Social Responsibility, Stock Prices, and Tax Policy. Can. J. Econ./Revue Can. D'économique 2013, 46, 1066-1084. [CrossRef]

18. Gherghina, S.C.; Simionescu, L.N. Does Entrepreneurship and Corporate Social Responsibility Act as Catalyst towards Firm Performance and Brand Value? Int. J. Econ. Financ. 2015, 7, 23-34. [CrossRef]

19. Singh, P.; Sethuraman, K.; Lam, J. Impact of Corporate Social Responsibility Dimensions on Firm Value: Some Evidence from Hong Kong and China. Sustainability 2017, 9, 1532. [CrossRef]

20. Buchanan, B.; Cao, C.X.; Chen, C. Corporate Social Responsibility, Firm Value, and Influential Institutional Ownership. J. Corp. Financ. 2018, 52, 73-95. [CrossRef]

21. Lee, M.T. Corporate Social Responsibility and Stock Price Crash Risk: Evidence from an Asian Emerging Market. Manag. Financ. 2016, 42, 963-979. [CrossRef]

22. Hao, D.Y.; Qi, G.Y.; Wang, J. Corporate Social Responsibility, Internal Controls, and Stock Price Crash Risk: The Chinese Stock Market. Sustainability 2018, 10, 1675. [CrossRef]

23. Chen, J.; Hong, H.; Stein, J.C. Forecasting Crashes: Trading Volume, Past Returns, and Conditional Skewness in Stock Prices. J. Financ. Econ. 2001, 61, 345-381. [CrossRef]

24. Zhang, M.; Liu, Y.; Xie, L.; Ye, T. Does the Cutoff of "Red Capital" Raise a Red Flag? Political Connections and Stock Price Crash Risk. N. Am. J. Econ. Financ. 2017, 1, 89-109. [CrossRef]

25. Sila, V.; Gonzalez, A.; Hagendorff, J. Independent Director Reputation Incentives and Stock Price Informativeness. J. Corp. Financ. 2017, 47, 219-235. [CrossRef]

26. Callen, J.L.; Fang, A. Institutional Investor Stability and Crash Risk: Monitoring versus short-termism? J. Bank. Financ. 2013, 37, 3047-3063. [CrossRef]

27. Kousenidis, D.V.; Ladas, A.C.; Negakis, C.I. Accounting Conservatism Quality of Accounting Information and Crash Risk of Stock Prices. J. Econ. Asymmetries 2014, 6, 120-137. [CrossRef]

28. Xu, N.; Jiang, X.; Chan, K.C.; Yi, Z. Analyst Coverage, Optimism, and Stock Price Crash Risk: Evidence from China. Pac.-Basin Financ. J. 2013, 11, 217-239. [CrossRef]

29. Luo, J.; Du, X. Media Coverage, Institutional Environment and Stock Price Crash Risk. Account. Res. 2014, 9 , 53-59.

30. Callen, J.L.; Fang, X. Religion and Stock Price Crash Risk. J. Financ. Quant. Anal. 2015, 50, 169-195. [CrossRef]

31. Bhargava, R.; Faircloth, S.; Zeng, H. Takeover Protection and Stock Price Crash Risk: Evidence from State Antitakeover Laws. J. Bus. Res. 2017, 1, 177-184. [CrossRef]

32. Petrovits, C. Corporate-Sponsored Foundations and Earnings Management. J. Account. Econ. 2006, 41, 335-361. [CrossRef]

33. Prior, D.; Surroca, J.; Tribó, J.A. Are Socially Responsible Managers Really Ethical? Exploring the Relationship Between Earnings Management and Corporate Social Responsibility. Corp. Gov. Int. Rev. 2008, 16, 160-177. [CrossRef]

34. Krishnamurti, C.; Shams, S.; Velayutham, E. Corporate Social Responsibility and Corruption Risk: A Global Perspective. J. Contemp. Account. Econ. 2018, 14, 1-21. [CrossRef]

35. Li, F. Annual Report Readability, Current Earnings, and Earning Persistence. J. Account. Econ. 2008, 45, 221-247. [CrossRef]

36. Gao, F.; Lisic, L.L.; Zhang, I. Commitment to Social Good and Insider Trading. J. Account. Econ. 2014, 57, 149-175. [CrossRef]

37. Lu, C.; Zhao, X.; Dai, J. Corporate Social Responsibility and Insider Trading: Evidence from China. Sustainability 2018, 10, 3163. [CrossRef] 
38. Cui, J.; Jo, H.; Na, H. Does Corporate Social Responsibility Affect Information Asymmetry? J. Bus. Ethics. 2018, 148, 549-572. [CrossRef]

39. Jo, H.; Harjoto, M.A. Corporate Governance and Firm Value: The Impact of Corporate Social Responsibility. J. Bus. Ethics 2011, 103, 351-383. [CrossRef]

40. Jo, H.; Harjoto, M.A. The Causal Effect of Corporate Governance on Corporate Social Responsibility. J. Bus. Ethics 2012, 106, 53-72. [CrossRef]

41. Campbell, J.L. Why would Corporations Behave in Socially Responsible Ways? An Institutional Theory of Corporate Social Responsibility. Acad. Manag. Rev. 2007, 32, 946-967. [CrossRef]

42. Minor, D.; Morgan, J. CSR as Reputation Insurance: Primum Non Nocere. Calif. Manag. Rev. 2011, 53, 40-59. [CrossRef]

43. Matten, D.; Crane, A. Corporate Citizenship: Toward an Extended Theoretical Conceptualization. Acad. Manag. Rev. 2005, 30, 166-179. [CrossRef]

44. Hategan, C.D.; Sirghi, N.; Curea-Pitorac, R.I.; Hategan, V.P. Doing Well or Doing Good: The Relationship between Corporate Social Responsibility and Profit in Romanian Companies. Sustainability 2018, 10, 1041. [CrossRef]

45. Liang, Q.; Zeng, H. Reform of Independent Director System, Independence of Independent Directors and Stock Price Crash Risk. Manag. World 2016, 3, 144-159.

46. Adams, R.; Hermalin, B.; Weisbach, M. The Role of Boards of Directors in Corporate Governance: A Conceptual Framework and Survey. J. Econ. Lit. 2010, 48, 58-107. [CrossRef]

47. Fama, E.F.; Jensen, M.C. Separation of Ownership and Control. J. Law Econ. 1983, 26, 301-325. [CrossRef]

48. White, J.; Woidtke, T.; Black, H.; Schweitzer, R. Appointments of Academic Directors. J. Corp. Financ. 2014, 28, 135-151. [CrossRef]

49. Brick, E.; Palmon, O.; Wald, J. CEO Compensation, Director Compensation, and Firm Performance: Evidence of Cronyism? J. Corp. Financ. 2006, 12, 403-423. [CrossRef]

50. Francis, B.; Hasan, I.; Wu, Q. Professors in the Boardroom and Their Impact on Corporate Governance and Firm Performance. Financ. Manag. 2014, 44, 547-581. [CrossRef]

51. Adams, R.B.; Ferrera, D. A Theory of Friendly Boards. J. Financ. 2007, 62, 217-250. [CrossRef]

52. Motta, E.M.; Uchida, K. Institutional Investors, Corporate Social Responsibility, and Stock Price Performance. J. Jpn. Int. Econ. 2018, 47, 91-102. [CrossRef]

53. Kim, J.B.; Li, Y.; Zhang, L. CFOs versus CEOs: Equity Incentives and Crashes Risk: Firm-level Analysis. J. Financ. Econ. 2011, 101, 713-730. [CrossRef]

54. Kim, J.B.; Li, Y.; Zhang, L. Corporate Tax Avoidance and Stock Price Crash Risk: Firm-level Analysis. J. Financ. Econ. 2011, 100, 639-662. [CrossRef]

55. Wang, Y.; Liu, H.; Wu, L. Information Transparency, Institutional Investors and Stock Price Synchronicity. J. Financ. Res. 2009, 12, 162-174.

56. Xu, N.; Li, X.; Yuan, Q.; Chan, K.C. Excess Perks and Stock Price Crash Risk: Evidence from China. J. Corp. Financ. 2014, 25, 419-434. [CrossRef]

(c) 2019 by the authors. Licensee MDPI, Basel, Switzerland. This article is an open access article distributed under the terms and conditions of the Creative Commons Attribution (CC BY) license (http:// creativecommons.org/licenses/by/4.0/). 